Boris Popov ${ }^{1}$ Dragana Jelić Sara Raković Jelena Matanović

University of Novi

Sad, Faculty of Philosophy, Department of Psychology

${ }^{1}$ Corresponding email: boris.popov@ff.uns.ac.rs

Primljeno: 19. 07. 2018. Primljena korekcija: 20. 08. 2018. Prihvaćeno za štampu: 17. 09. 2018.

\section{EMOTIONS AND WORK BURNOUT FROM THE REBT PERSPECTIVE: A SHORT-TERM PROSPECTIVE STUDY ${ }^{2}$}

The main objective of the study was to test REBT model of emotion in prediction of burnout. It was hypothesized that dysfunctional negative emotions (DNE) would positively predict burnout, positive emotions (PE) would negatively predict buronut, while functional negative emotions (FNE) were hypothesized to be uncorrelated to burnout. To test those assumptions, a short-term, 12 week prospective study was carried out (three measurements, with the interval of 6 weeks). A sample of 197 employees took part in the first measurement ( $60.3 \%$ women); however, due to sample attrition, 113 (64.6\% women) underwent all three measurements (Little's MCAR test n.s., which indicates that the data were missing completely at random). Respondents completed the Work burnout scale from the Copenhagen Burnout Inventory, and the Inventory of functional and dysfunctional emotions. It has been shown that the reversed causal model displayed greater fit indices in comparison with the causal model, meaning that it is more likely that burnout will lead to subsequent emotions than vice-versa. What is more interesting is that in fact burnout had a stronger (although very similar) impact on FNE than it did on DNE. However, when measured simultaneously, it appears that the experience of emotions has greater effect on burnout than vice-versa. Moreover, in cross-sectional analysis (at Time 3), FNE had a greater (although very similar) unique effect on burnout than did DNE. In Time 2, only DNE exerted significant effect on burnout. Finally, PE largely did not predict burnout. The results were discussed in the context of REBT model of emotions. The limitations of the study were also highlighted and discussed.

Key words: dysfunctional negative emotions, functional negative emotions, positive emotions, REBT model of emotions, work burnout.

\footnotetext{
2 This research was supported by the Serbian Ministry of Education and Science (Grant No. 179022).
} 


\section{Introduction}

\section{Emotions at Work}

One of the most important areas within organisational psychology, and in the opinion of some authors, most neglected, is the consideration of the causes, characteristics and consequences of the expression of emotions at work (Muchinsky, 2000 ) as a key to the understanding of organisational behaviour (Bunk \& Magley, 2013), as well as of the results of stress transactions at work (Glasø, Vie, Holmdal, \& Einarsen, 2011). In the most general sense, by emotion we refer to an adaptive reaction of the body to relevant stimulus which involves four aspects: a cognitive and behavioural component, subjective experience and physiological arousal (Tiba \& Szentagotai, 2005). The basic theoretical framework we will adopt for understanding emotional experience in this paper will be rational emotive behaviour therapy (hereinafter referred to as REBT). REBT follows the ABC model according to which an activating event (A) leads to emotional, behavioural and cognitive consequences (Cs) by means of evaluative beliefs (B) (David, Szentagotai, Eva, \& Macavei, 2005; Tiba \& Szentagotai, 2005). According to this model, favourable events are accompanied by positive emotions, unfavourable events by negative. Since both categories of emotion can be both functional (healthy, adaptive, self-enhancing) and dysfunctional (unhealthy, maladaptive and self-defeating), depending on whether the person is governed by rational or irrational beliefs, by combining these outcomes we arrive at four possible types of emotional reaction (David et al., 2005): A) dysfunctional negative emotions (e.g., anxiety, depression, anger, guilt, hurt); B) dysfunctional positive emotions (e.g., euphoria); C) functional negative emotions (e.g., concern, sadness, annoyance), and D) functional positive emotions (e.g. joy, happiness, satisfaction). The difference between functional and dysfunctional emotions is seen both in their quantity (i.e., intensity) and in their quality. The first serve the fulfilment of preferences and long-term goals, while the second category serves the satisfaction of demands and short-term benefit. Accordingly, dysfunctional emotions hinder the achievement of objectives and reduce motivation and adaptability (Mogoase \& Stefan, 2013; Tiba \& Szentagotai, 2005), while functional emotions tend to be related to the achievement of goals (David et al., 2005; Phillips, Smith, \& Gilhool, 2002), the improvement of professional performance (Ashby, Valentin, \& Turken, 2002), but also with changes at the cognitive level such as improvements in the working verbal memory (Carpenter, Peters, Västfjäll, \& Isen, 2013; Gray, 2001). It is natural to expect stressors in the workplace to "cause" negative emotions, but it should be kept in mind that functional emotions, unlike dysfunctional ones, are associated with adaptability and the improvement of professional performance (Ashby et al., 2002). In other words, despite the fact that negative emotions negatively reflect on the attitudes and behaviour of employees (Bagozzi, 2003; Yang \& Diefendorff, 2009), their effects are considerably more harmful when they are dysfunctional. 
Although there have been many studies into general affective states, insufficient attention has been given to the role of specific emotions in stressful experiences at work (Brief \& Weiss, 2002). It has been shown that emotions can affect attitudes such as job satisfaction and commitment to the organisation (Grandey, Tam, \& Brauburger, 2002; Mignonac \& Herrbach, 2004), but also counter-productive behaviours such as tardiness, absenteeism, turnover, aggression and revenge (Glasø et al., 2011; Glomb, Steel, \& Arvey, 2002; Spector \& Fox, 2005; Tripp \& Bies, 2004; Yang \& Diefendorff, 2009). Common effects of negative emotions also include reduced interpersonal communication and work performance (Bagozzi, 2003). In comparison with negative emotions and their effects on different aspects of human functioning, positive emotions have been largely neglected both in basic and clinical research. Since conclusions reached in regard to negative emotions cannot justifiably be applied to positive emotions, the latter need to be studied separately. The research hitherto has shown that positive emotions in employees promote their cognitive flexibility and enhance problem-solving and decision-making (Ashby, Isen, \& Turken, 1999; Isen, 2008), interpersonal cooperation (Fredrickson, 1998) and the setting of challenging personal goals (Locke \& Latham, 1990), and increase tolerance of ambiguity (Katsaros \& Nicolaidis 2012). One finding has suggested that the frequency of positive emotions is a better predictor of job satisfaction than their intensity (Fisher, 2000). Flow experiences at work have been associated with positive emotions (Eisenberger, Jones, Stinglhamber, Shanock, \& Randall, 2005; Tobert \& Moneta, 2013), improved performance (Demerouti, 2006) and reduced exhaustion levels (Mäkikangas, Bakker, Aunola, \& Demerouti, 2010). However, Fernet et al. (2014) found out that obsessive passion for work on the part of teachers had a direct positive effect on emotional exhaustion 12 months later.

\section{Emotions and Burnout}

Burnout may be defined as "a state of physical, emotional and mental exhaustion that results from long-term involvement in work situations that are emotionally demanding" (Schaufeli \& Greenglass, 2001, p. 501). High emotional demands at work are most often positively correlated with indicators of reduced welfare such as emotional exhaustion, distress and psychosomatic complications, and negatively with attitudes towards work (such as job satisfaction), and job performance (Fisher \& Ashkanasy, 2000; Hülsheger \& Schewe, 2011; Johnson \& Indvik, 2000; Lively, 2006). Burnout syndrome is positively correlated with increased turnover and absenteeism, and negatively with affective commitment to the organisation (see Popov, Miljanović, Stojaković, \& Matanović, 2013). While job satisfaction has pleasant emotional associations, work-related stress and burnout have unpleasant associations, most often frustration, dissatisfaction, anger and despair (Muchinsky, 2000). Chronic dissatisfaction is associated with a lack of commitment to the company and with emotional exhaustion (Testa, 2001) as a 
primary dimension of burnout. In addition, the experience of anger and hostility can be an early marker of prolonged stress, as well as of poor mental and physical health and burnout (Chang, 2013; Eng, Fitzmaurice, Kubzansky, Rimm, \& Kawachi, 2003; Fitzgerald, Haythornthwaite, Suchday, \& Ewart, 2003; Smith, Roman, Dollard, Winefield, \& Siegrist, 2005; van Vegchel, de Jonge, Meijer, \& Hamers, 2001). Some of the main consequences of anger are reduced work performance, cognitive difficulties and harassment and undermining of superiors (Allcorn, 1994; Douglas \& Martinko, 2001; Lively \& Powell, 2006; Sloan, 2012; Stets \& Tsushima, 2001). Anxiety and depression are negatively correlated with job satisfaction and work engagement (Andrea et al., 2004; Andrea, Bültmann, van Amelsvoort, \& Kant, 2009; Innstrand, Langballe, \& Falkum, 2012), which some authors consider a positive antithesis to burnout syndrome (Maslach \& Leiter, 2008). In one study on police officers in Poland (Basinska, Wiciak, \& Dåderman, 2014), it was concluded that low-arousal negative emotions partially mediated the relationship between fatigue and emotional exhaustion. On the other hand, high-arousal positive and negative emotions proved to be partial mediators between fatigue and disengagement (see Bedyńska \& Żołnierczyk-Zreda, 2015). Research carried out on employees in Serbia showed that positive experience at work promoted work engagement, but did not significantly affect burnout, in contrast to negative experience (Popov, Raković, \& Jelić, 2017; Zellars et al., 2004). Van Katwyk et al. (1995) suggest that emotions are more closely correlated with work-related stress and burnout than cold cognitions (as cited in Fisher, 2000).

\section{The Present Study}

Having in mind that emotions are the most obvious manifestation of burnout, as the ultimate outcome of chronic stress, the aim of this study is to identify specific emotions that could be early markers of work-related burnout. In other words, the main objective of this study has been to verify the REBT emotional model in the prediction of burnout, given that it has not yet been tested in the work environment. Taking into consideration the results of previous research, and the theoretical framework of the model to be used, some expectations can be laid out. Firstly, it is expected that functional negative emotions will not correlate strongly with burnout, whilst dysfunctional negative emotions will have a positive correlation with it. It is also expected that positive emotions are negatively correlated with burnout, that is, that they act as a potential protective factor that might prevent its development.

Specifically, the following hypotheses were formulated:

1. Dysfunctional negative emotions (DNE) will have a positive cross-lagged effect on burnout (WB); DNE_T1 $\rightarrow$ WB_T2, and DNE_T2 $\rightarrow$ WB_T3

2. Functional negative emotions (FNE) will have insignificant both crosssectional and cross-lagged effects on burnout (WB) 
3. Positive emotions (PE) will have a negative cross-lagged effect on burnout (WB); PE_T1 $\rightarrow$ WB_T2, and PE_T2 $\rightarrow$ WB_T3

\section{Method}

\section{Sample and Procedure}

The present study falls under the short-term prospective type of study. A total of three measurements were taken, with an interval of six weeks between each measurement (a total of 12 weeks), during a period between March and May 2013. The instruments were administered in individual and group settings. The subjects answered the same questionnaire three times, with the exception of the list of demographic questions, which was part of the battery only for the first occasion. The study was anonymous - subjects were asked to enter a code by means of which their responses could be reconciled. The sample for this study comprised employed individuals from the area of Vojvodina from both private and public sectors - administrative staff, IT engineers and scientific and healthcare professionals. 197 respondents took part in the baseline measurement (Time 1). After elimination of two due to the large amount of missing data, and one as an outlier, the final sample comprised 194 subjects (Male $=72,37.1 \%$; Female $=117,60.3 \%$; 5 no response, $2.6 \%$ ). The average age of the subjects was 40 , with an average of 14 years of service (in the range 1-38 years). The largest group had a university education, 84 of them, 73 had a formal high-school education, 16 had completed vocational college or had a masters or doctorate, while three subjects had only completed primary school. For the second and third measurement, the sample - not unexpectedly - underwent attrition, such that a total of 113 subjects underwent all three measurements. The non-significance of Little's test $(\chi 2=128.28, d f$ $=136, p>.10$ ) suggested that data missing due to the attrition were missing completely at random (MCAR). Because the data were MCAR, it was safe to listwise delete cases with missing values.

\section{Instruments}

WB Scale (Work Burnout; Kristensen et al., 2005; Serbian version: Berat, Jelić, \& Popov, 2016). WB is a scale for measuring the intensity of burnout. It assesses the degree of physical and psychological fatigue and exhaustion that is perceived by the person as being related to his/her work. It consists of seven items (e.g., "Is your work emotionally exhausting?"), with a five-point response format (from never/almost never to always). The original scoring was used (the response never/almost never is calculated as 0 , seldom as 25 , sometimes as 50 , often as 75 and always as 100), and the total score is obtained as an arithmetic mean of the responses to all seven items. Earlier studies have shown that the scale 
is valid and reliable (Milfont, Denny, Ameratunga, Robinson, \& Merry, 2008), and verification on samples of employees in Serbia have shown that it has a high internal consistency $(\alpha=.88)$, as well as correlating to distress in the expected manner $(r=.54)$, turnover intentions ( $r$ ranging from .36 to .40$)$ and job satisfaction $(r$ ranging from .29 to -.44; Berat et al., 2016).

The Inventory of Functional and Dysfunctional Emotions. This inventory is actually a list of emotions reflecting the division of emotions according to the REBT theoretical model. The questionnaire developed for this study comprised a total of 21 emotions divided into three groups - positive emotions (PE; e.g., happiness), functional negative (FNE; e.g., sadness) and dysfunctional negative emotions (DNE; e.g., anger). For the final analysis in this research, three emotions were used as typically representing each group (see David et al., 2005). A list of all the emotions can be found in Table 1.

Table 1

List of positive, functional negative, and dysfunctional negative emotions used in the study

\begin{tabular}{lll}
\hline $\begin{array}{l}\text { Positive emotions } \\
\text { (PE) }\end{array}$ & $\begin{array}{l}\text { Functional negative } \\
\text { emotions (FNE) }\end{array}$ & $\begin{array}{l}\text { Dysfunctional negative } \\
\text { emotions (DNE) }\end{array}$ \\
\hline Satisfaction* & Nervousness & Depressiveness* \\
Inspiration & Tense & Hurt \\
Happiness* & Sadness* & Disappointment \\
Enthusiasm & Concern* & Guilt \\
Positive arousal & Fear & Anger* \\
Pride & Annoyance* & Shame \\
Excitement* & Envy & Anxiety* \\
\hline
\end{tabular}

Note. Emotions marked with asterisk were used in path analysis (see text for details).

In addition to the aforementioned questionnaires, the subjects answered a list of demographic questions. They were asked to give their gender, age, highest level of formal education achieved, total years of service and years of service in the organisation they currently worked in, and the average number of hours worked per week.

\section{Data Analyses}

Firstly, the SPSS software package for Windows, version 22.0, was used for descriptive statistics and calculation of correlations between the variables, while testing of the hypothesised model was carried out in the program EQS 6.1 for 
Windows (Bentler, 2006). A total of five path analysis models were tested (see below for their specifications). Auto-regression effects were included in order to control for baseline levels for each endogenous variable, as suggested by Gollob and Reichard (1991; see also Hakanen, Schaufeli, \& Ahola, 2008).

In testing the adequacy of the research model, the following absolute fitness indices were taken into consideration: (1) the Sattora-Bentler $\chi^{2}$ goodness-offit statistic, (2) the root mean square error of approximation (RMSEA), and (3) the standardised root mean-square residual (SRMR). Because $\chi^{2}$ is sensitive to sample size, three relative goodness-of-fit measures were calculated as well: (1) normed fit index (NFI), (2) non-normed fit index (NNFI) and (3) comparative fit index (CFI). Values smaller than .05 for RMSEA may indicate a good fit, smaller than .08 are indicative of an acceptable fit, and values greater than .10 may indicate a serious problem (Browne \& Cudeck, 1993; Kline, 2010). For the three relative fit indices, values greater than .90 may indicate a good fit (Hoyle, 1995). However, Hu and Bentler (1999) have recommended a slightly higher threshold, such as .95 for the CFI. For the SRMR, Hu and Bentler (1999) have set a threshold of $\leq .08$ for acceptable fit, but Kline (2010) has suggested that this value is not a very demanding standard. Finally, the Akaike Information Criterion was calculated and reported.

\section{Results}

Table 2 displays the means, standard deviations, Cronbach's alpha and correlations for the (dys)functional negative emotions, positive emotions and work burnout for Time 1, Time 2, and Time 3. 
Boris Popov, Dragana Jelić, Sara Raković, and Jelena Matanović

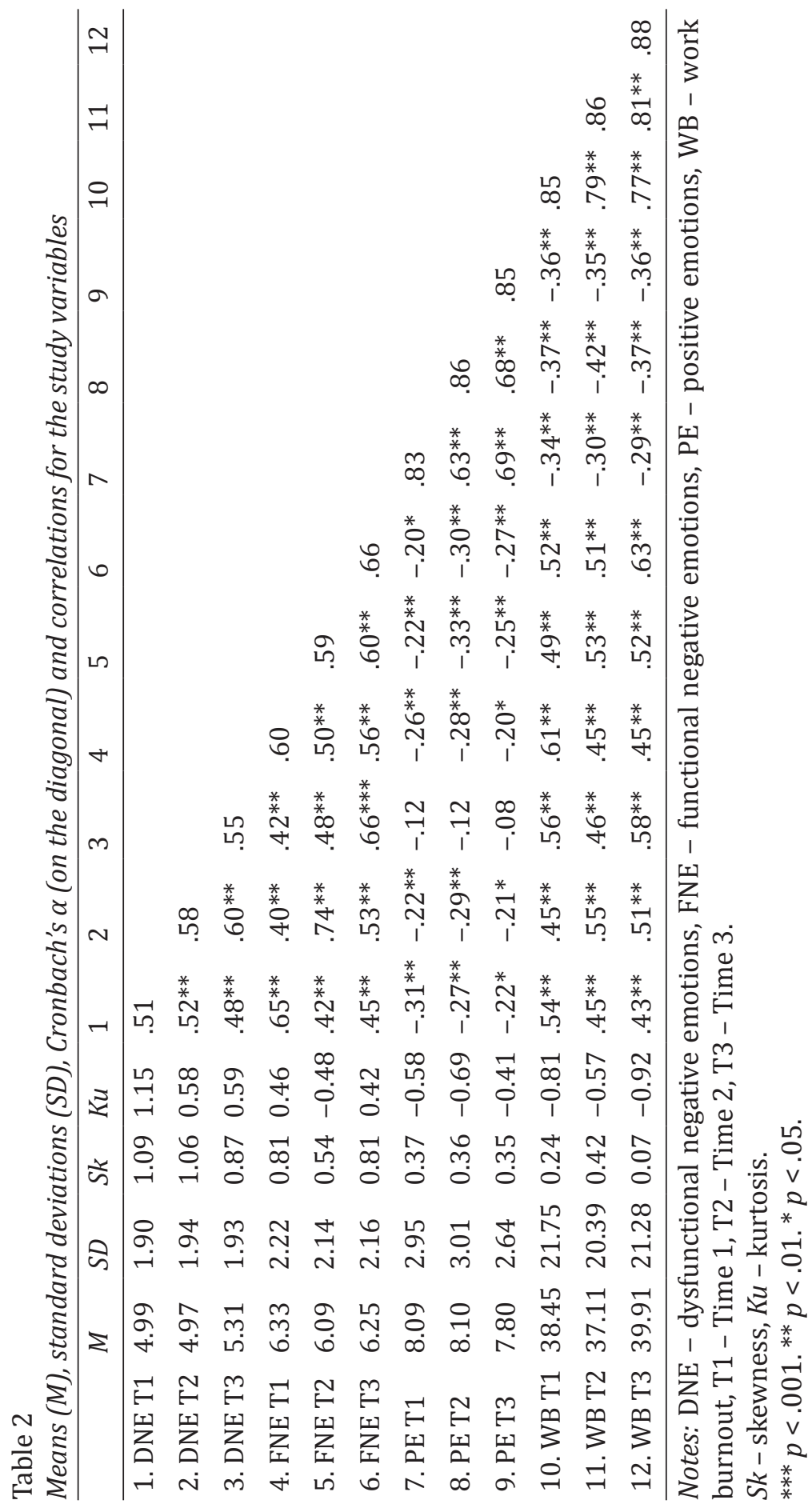

primenjena psihologija 2018/3 
Respondents in this study achieved somewhat lower scores on burnout than in others, similarly heterogeneous samples (Berat et al., 2016). The alpha levels for the measures of positive emotions and work burnout indicate an acceptable level of inter-item consistency with Cronbach's alpha coefficients of .82 or higher, while levels of these coefficients for the measures of functional and dysfunctional emotions are somewhat lower, ranging from .51 to .66 . The moderately high correlation between dysfunctional and functional negative emotions are in line with expectations, as well as their negative correlation with positive emotions. Also, work burnout correlates positively with negative emotions, while its relationships with positive emotions are negative in all three measures.

Table 3

Goodness - of - fit indices for the tested models, $N=113$

\begin{tabular}{llllllll}
\hline Model description & $\chi 2$ & $d f$ & RMSEA & SRMR & NNFI & CFI & AIC \\
\hline Causality mode M1 $(\mathrm{E} \rightarrow \mathrm{WB})$ & $98.50^{* * *}$ & 42 & .11 & .16 & .88 & .93 & 14.50 \\
Full panel model M2 (WB↔E) & $68.52^{* * *}$ & 36 & .09 & .07 & .92 & .96 & -3.48 \\
$\begin{array}{l}\text { Reversed causality model } \\
\text { (WB } \rightarrow \text { M) }\end{array}$ & $72.93^{* *}$ & 40 & .09 & .07 & .93 & .96 & -7.06 \\
Respecified M3a & 42.61 & 37 & .04 & .05 & .98 & .99 & -31.39 \\
Respecified M3b & 33.15 & 37 & .00 & .04 & 1.00 & 1.00 & -40.85 \\
\hline
\end{tabular}

Notes. Coefficients and numbers refer to model fit indices: $\chi 2$ - Satorra-Bentler chi-square, $d f$ - degrees of freedom, RMSEA - root mean square error of approximation, SRMR - standardized root mean-square residual, NNFI - non-normed fit index, CFI - comparative fit index, AIC - Akaike information criterion, E - emotions, WB - work burnout. ${ }^{* * *} p<.001 .{ }^{* *} p<.01$.

In order to test causal relationships between three groups of emotions and burnout, the results of three path analysis models were compared. Table 3 presents the fit indices of the competing "causal", the "reversed causal", and the "full panel" model. The causal model postulates a cross-lagged effect of dysfunctional negative and positive emotions on subsequent burnout $(\mathrm{E} \rightarrow \mathrm{WB})$. The reversed causality model, on the other hand, posits that burnout has a direct cross-lagged effect on subsequent dysfunctional negative, functional negative, and positive emotions $(\mathrm{WB} \rightarrow \mathrm{E})$. Finally, the full panel model combines the previous two dysfunctional negative, and positive emotions predict subseqent burnout, while burnout predicts all three types of emotional states $(E \leftrightarrow W B)$. In all three models, we allowed autoregression for all variables in the model from T1 to T3. We also allowed for the error terms of DNE and FNE to be correlated. There is a theoretical rationale for that - according to the REBT model of emotions, dysfunctional emo- 
tions also include their functional counterparts (David et al., 2005), thus making them substantially correlated.

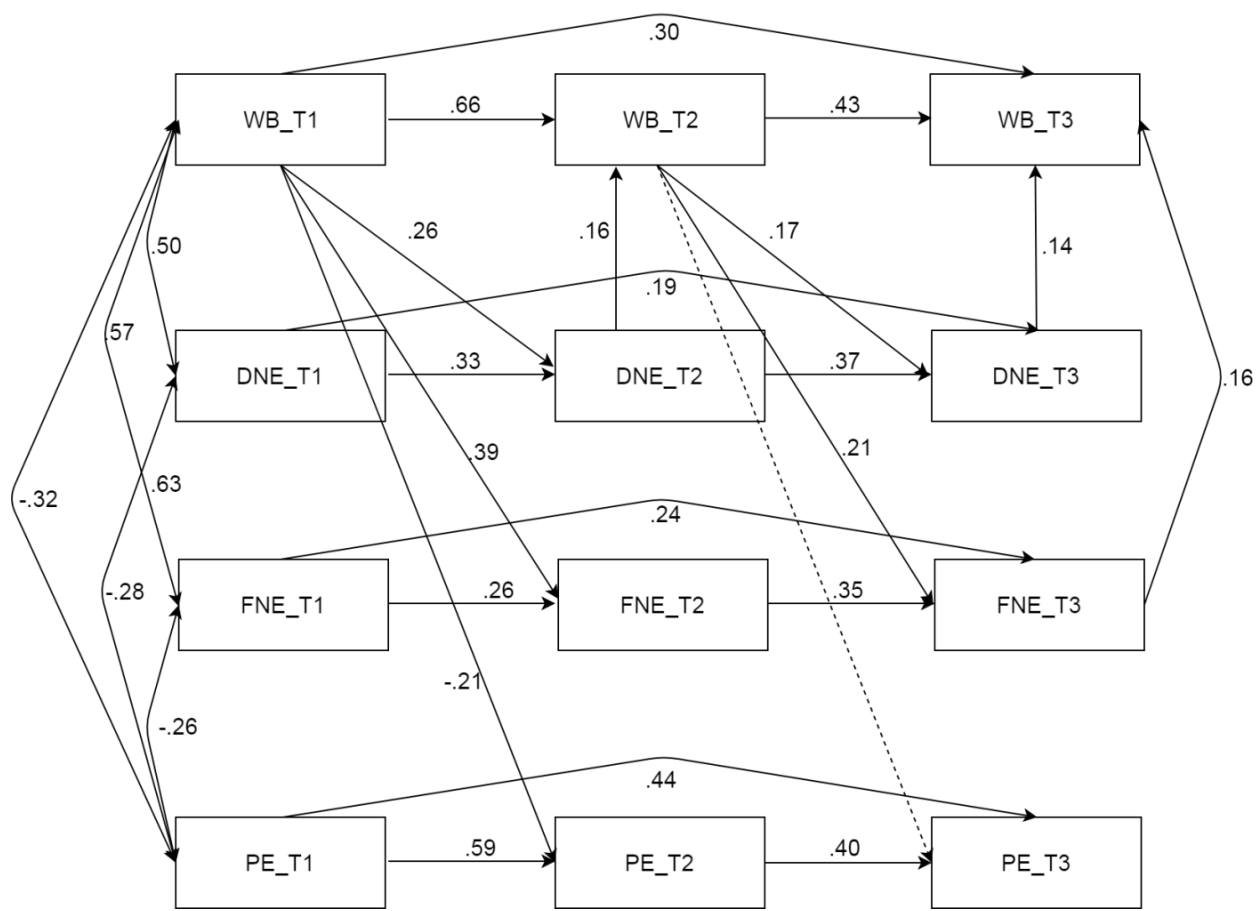

Figure 1. Standardized coefficients for the Respecified reversed causality model(M3b)

Note. DNE_T1 - dysfunctional negative emotions in Time 1; FNE_T1 - functional negative emotions in Time 1; PE_T1 - positive emotions in Time 1; WB_T1 - work burnout in Time 1; DNE_T2 - dysfunctional negative emotions in Time 2; FNE_T2 - functional negative emotions in Time 2; PE_T2 - positive emotions in Time 2; WB_T2 - work burnout in Time 2; FNE_T3 - functional negative emotions in Time 3; PE_T3 - positive emotions in Time 3; WB_T3 - work burnout in Time 3. Dashed lines represent insignificant paths.

Table 3 shows fit indices for the tested path models. The causality model did not reach acceptable fit indices. For the other two models chi-square was also statistically significant, but approximate fit indexes were more favourable. AIC suggested the reversed causality model to be the better model of the two, though still not passing the exact-fit hypothesis. From inspection of the standardised residual matrix it is evident that the proposed (reverse causality) model underpredicts the association of burnout in T2 with DNE in T2, and burnout in T3 with both and FNE and DNE in T3. So, we made three respecifications to the model, adding direct paths from WB_T2 to DNE_T2, and WB_T3 to both DNE_T3 and FNE_T3. 
These respecifications resulted in the model passing both exact-fit, and close-fit hypotheses (Kline, 2010). However, we also wanted to test if a link from emotions to burnout would yield better model fit, so we made one final respecification. Namely, three added parameters to the Respecified M3 were changed in direction, one leading from DNE_T2 to WB_T2, the second FNE_T3 to WB_T3, and the third from DNE_T3 to WB_T3. That model showed even better fit to the data, so we finally decided to retain the Respecified reversed causality model, called M3b. This model is presented in Figure 1.

The standardised path coefficients linking dysfunctional, functional negative and positive emotions to work burnout are shown in Figure 1. Work burnout at Time 1 had a positive cross-lagged effect on both groups of negative emotions at Time 2, DNE_T2 $(\beta=.26)$, and FNE_T2 $(\beta=.39)$. Moreover, burnout at Time 1 had a negative cross-lagged effect on positive emotions $(\beta=-.21)$. Finally, burnout at Time 2 significantly predicted both dysfunctional $(\beta=.17)$ and functional $(\beta=.21)$ negative emotions at Time 3 , while not exerting a significant effect on positive emotions at Time 3 . What we also learned from the tested models is that when measuring at the same point it is more likely that negative emotions will predict burnout than vice versa $\left(\right.$ DNE_T2 $_{-} \rightarrow \mathrm{WB}_{-} \mathrm{T} 2, \beta=.16$; DNE_T3 $\rightarrow$ WB_T3, $\beta=$ $.14 ;$ FNE_T3 $\rightarrow$ WB_T3, $\beta=.16$ ).

In conclusion, there is insufficient evidence to retain any of the three postulated hypotheses.

\section{Discussion}

The main objective of this paper was to test the REBT emotional model in predicting workplace burnout. Accordingly, the key question that served as our starting point for the research was: "Which of the three groups of emotions - functional, dysfunctional negative or positive - best predict burnout as an ultimate consequence of chronic exposure to workplace stressors?" In order to answer this question we tested a total of five path analysis models, all of which included three types of emotions, as well as burnout. The so-called causality model $(\mathrm{E} \rightarrow \mathrm{WB})$ and reversed causality model (WB $\rightarrow E$ ) were tested. The REBT model posits that dysfunctional emotions also include their functional counterparts, while the opposite is not necessarily true - additional reason to treat them separately for research purposes. When regarded as a whole, the findings do not support the hypotheses set forth. On the contrary, it has been shown to be more likely that burnout will lead to subsequent emotions than vice-versa. However, when measured simultaneously, it appears that the experience of emotions has greater effect on burnout than vice-versa. What is more interesting is that in fact burnout had a stronger (although very similar) impact on FNE than it did on DNE. Moreover, in crosssectional analysis (at Time 3), FNE had a greater (although actually very similar) 
unique effect on burnout than did DNE, even though the prediction was that they would not be correlated to it.

There are three key findings that warrant discussion. Firstly, the reversed causal model displayed greater indices of fit in comparison with the causal model. It has already been stated that the prolonged experience of unhealthy negative emotions can result in workplace burnout (Eng et al., 2003; Fitzgerald et al., 2003; Smith et al., 2005; Testa, 2001; van Vegchel et al., 2001).

However, the great majority of the studies whose findings we have cited either used multiple regression for data analysis (e.g., Little, Simmons, \& Nelson, 2007; Zellars et al., 2004), or did not test reversed causality models in structural equation modelling (WB $\rightarrow E$; e.g., Brackett et al., 2010). From what we have learned from the model obtained in this study, it is possible that burnout at a particular point in time leads to subsequent feelings of anxiety, anger, concern, depression, sadness etc. (in other words, both DNE and FNE). The finding that the direction of the correlation between the emotions and burnout is different in cross-sectional analysis is a rather puzzling finding one and needs further investigation.

Secondly, with the exeption of Time 2 (in which only DNE exerted significant effect on WB), the results suggest that FNEs and DNEs have a similar (crosssectional) effect to burnout. We can look to a number of facts for an explanation for these findings. Firstly, there is justification for the assumption that functional emotions also drain our resources. Hence if they are present in the workplace at a high intensity and frequency, this will ultimately lead to stress and burnout. Further, as both practice and empirical findings have shown, in comparison with DNEs, FNEs are experienced more frequently, and could thus play a more significant role in the development of burnout at work (Andrea et al, 2004; Innstrand et al., 2012). This would mean that when considering the effects of emotions on different aspects of the functioning of employees, it is not enough to take into account only the quantitative and qualitative aspects of the differences between emotions, but also the frequency with which they are experienced (Fisher, 2000). As has already been noted, dysfunctional emotions always include their functional counterparts, while the opposite is not necessarily true, and so it is possible that in the research, the frequency of occurrence of functional emotions has been overvalued, while the frequency of dysfunctional emotions has been undervalued. Additionally, it is possible that in everyday Serbian speech the names of functional emotions predominate over the names of the dysfunctional (concern and frustration vs. anxiety, anger), and also that subjects generally have trouble verbally differentiating between those two types of emotion. Finally, the context of the workplace is fertile ground for subjects to give socially desirable responses out of a fear of negative consequences. For this reason expressing dysfunctional emotions in the workplace is in a way censored, and employees are more inclined to display functional emotions, which can hinder the identification of experienced dysfunctional emotions. In view of this, it would be useful to measure emotions while they are still "hot", i.e., less susceptible to conscious manipulation. 
Thirdly, contrary to initial expectations for this research, i.e., the assumptions of the REBT model, it has been shown that in our research positive emotions largely do not predict burnout (even though the opposite is true for WB_T1 $\rightarrow$ PE_ T2). Supporting this, in earlier research carried out on our sample (Popov et al., 2017), it was found that positive experience at work promoted work engagement, but did not have a significant effect on burnout (contrary to the negative experiences, which did have an effect on burnout). It is very likely that positive emotions potentially correlate more strongly to the so-called positive indicators of organisational behaviour (e.g., work engagement, pro-social organisational behaviour, etc.). As compared to the negative, positive emotions are significantly less frequently the subject of academic attention, a situation we sought to remedy by way of this research, having in mind the effects they have on various aspects of workplace functioning (Ashby et al., 1999; Fredrickson, 1998; Isen, 2008; Katsaros \& Nikolaidis, 2012; Locke \& Latham, 1990;). However, for future research it would be useful if positive indicators were taken into consideration and not only negative indicators of organisational behaviour. Considering previous findings, it seems that positive emotions have greater predictive power for the first group of indicators and negative emotions for the second group (Andrea et al., 2009; Hakanen et al., 2008; Muchinsky, 2000).

On this basis we can make the assumption that promoting positive emotions is not an effective strategy for prevention of burnout syndrome. Rather its development can be prevented by the reduction of negative, primarily dysfunctional emotions. Earlier findings (Mäkikangas et al., 2010) have shown that a positive affective state in relation to work is associated with a reduced level of emotional exhaustion (that being the most obvious manifestation of burnout; see also Brackett et al., 2010). Nevertheless, the results of this research suggest that the presence of positive emotions is not enough to reduce the risk of burnout syndrome developing. It would be more effective to work on the elimination or at least the reduction of the stressors at work that are the triggers for negative emotional responses. Since it is not possible to significantly impact many stressors, work could be done on modifying the way employees perceive them. Although there are serious methodological difficulties in measuring different types of emotion, they doubtless impact organisational behaviour and the outcome of stress transactions at work (Allcorn, 1994; Bunk \& Magley, 2013; Douglas \& Martinko, 2001; Glasø et al., 2011; Lively \& Powell, 2006; Sloan, 2012; Stets \& Tsushima, 2001). Hence the improvement of emotional regulation skills would yield multiple benefits both for employees and for the organisation they are employed by. As suggested by the findings of earlier research (Mogoase \& Stefan, 2013; Tiba \& Szentagotai, 2005), the reduction and/or elimination of dysfunctional emotions in employees would contribute to the resolution of many work-related problems such as difficulty achieving long-term goals, insufficient motivation and adaptability in frequently changeable working conditions. 


\section{Conclusions and Recommendations for the Future}

To end with, some concluding remarks. Based on the results of the study conducted, there is no firm evidence that functional emotions can be reliably differentiated from dysfunctional emotions in the prediction of job burnout. Rather, it seems that both are relevant and contribute in similar ways to the understanding of burnout. Also, contrary to the initial assumptions, positive emotions play no protective role in burnout prevention. In future research, more attention would need to be focused on ways to more precisely measure emotions in the workplace (e.g., via their behavioural indicators), since it is possible that subjects verbally code their emotions in idiosyncratic ways and that the names of emotions do not have universally accepted meanings. Additionally, the research would ideally be conducted on a larger sample in order to increase the statistical power and generalisability of the results. Finally, it would be advisable to extend the time interval between measurements in order to better encompass the process of the development of burnout.

\section{References}

Allcorn, S. (1994). Anger in the workplace: Understanding the causes of aggression and violence. Westport: Quorum Books. doi:10.2307/253542

Andrea, H. H., Bültmann, H. H., Beurskens, A. M., Swaen, G. H., van Schayck, C. P., \& Kant, I. J. (2004). Anxiety and depression in the working population using the HAD Scale: Psychometrics, prevalence and relationships with psychosocial work characteristics. Social Psychiatry \& Psychiatric Epidemiology, 39(8), 637-646. doi:10.1007/s00127-004-0797-6

Andrea, H., Bültmann, U., van Amelsvoort, L. M., \& Kant, Y. (2009). The incidence of anxiety and depression among employees-The role of psychosocial work characteristics. Depression And Anxiety, 26(11), 1040-1048. doi:10.1002/ da. 20516

Ashby, F. G, Isen A. M., \& Turken A. U. (1999). A neuropsychological theory of positive affect and its influence on cognition. Psychological Review, 106(3), 529550. doi:10.1037//0033-295x.106.3.529

Ashby, F. G., Valentin, V. V., \& Turken, A. U. (2002). The effects of positive affect and arousal on working memory and executive attention. In S. Moore, \& M. Oaksford (Eds.), Emotional Cognition: From Brain to Behaviour (pp. 245-287). Amsterdam: John Benjamins. doi:10.1075/aicr.44.11ash

Bagozzi, R. P. (2003). Positive and negative emotions in organizations. In K. S. Cameron, J. E. Dutton, \& R. E. Quinn (Eds.), Positive Organizational Scholarship (pp. 176-193). San Francisco: Berrett-Koehler.

Basinska, B. A., Wiciak, I., \& Dåderman, A. M. (2014). Fatigue and burnout in police officers: the mediating role of emotions. Policing: An International 
Journal of Police Strategies \& Management, 37(3), 665-680. doi:10.1108/pijpsm-10-2013-0105

Bedyńska, S., \& Żołnierczyk-Zreda, D. (2015). Stereotype threat as a determinant of burnout or work engagement. Mediating role of positive and negative emotions. International Journal of Occupational Safety and Ergonomics, 21(1), 1-8. doi:10.1080/10803548.2015.1017939

Bentler, P. M. (2006). EQS 6 structural equations program manual. Encino, CA: Multivariate Software Inc.

Berat, N., Jelić, D., \& Popov, B. (2016). Serbian version of the Work Burnout Scale from the Copenhagen Burnout Inventory: Adaptation and psychometric properties. Applied Psychology, 9(2), 177-198. doi:10.19090/pp.2016.2.177-198

Brackett, M. A., Palomera, R., Mojsa-Kaja, J., Reyes, M. R., \& Salovey, P. (2010). Emotion-regulation ability, burnout, and job satisfaction among British secondary-school teachers. Psychology in the Schools, 47(4), 406-417. doi:10.1002/ pits.20478

Brief, A. P., \& Weiss, H. M. (2002). Organizational behavior: Affect in the workplace. Annual Review of Psychology, 53(1), 279-307. doi:10.1146/annurev. psych.53.100901.135156

Browne, M. W., \& Cudeck, R. (1993). Alternative ways of assessing model fit. In K. A. Bollen, \& J. S. Long (Eds.), Testing Structural Equation Models (pp. 1-9). Newbury Park, CA: Sage. doi:10.1177/0049124192021002005

Bunk, J. A., \& Magley, V. J. (2013). The role of appraisals and emotions in understanding experiences of workplace incivility. Journal of Occupational Health Psychology, 18(1), 87-105. doi:10.1037/a0030987

Carpenter, S. M., Peters, E., Västfjäll, D., \& Isen, A. M. (2013). Positive feelings facilitate working memory and complex decision making among older adults. Cognition \& Emotion, 27(1), 184-192. doi:10.1080/02699931.2012.698251

Chang, M. L. (2013). Toward a theoretical model to understand teacher emotions and teacher burnout in the context of student misbehavior: Appraisal, regulation and coping. Motivation and Emotion, 37(4), 799-817. doi:10.1007/ s11031-012-9335-0

David, D., Szentagotai, A., Eva, K., \& Macavei, B. (2005). A synopsis of rationalemotive behavior therapy (REBT); fundamental and applied research. Journal of Rational-Emotive and Cognitive-Behavior Therapy, 23(3), 175-221. doi:10.1007/s10942-005-0011-0

Demerouti, E. (2006). Job characteristics, flow, and performance: The moderating role of conscientiousness. Journal of Occupational Health Psychology, 11(3), 266-280. doi:10.1037/1076-8998.11.3.266

Douglas, S. C., \& Martinko, M. J. (2001). Exploring the role of individual differences in the prediction of workplace aggression. Journal of Applied Psychology, 86(4), 547-559. doi:10.1037//0021-9010.86.4.547

Eisenberger, R., Jones, J. R., Stinglhamber, F., Shanock, L., \& Randall, A. T. (2005). Flow experiences at work: For high need achievers alone?. Journal of Or- 
ganizational Behavior: The International Journal of Industrial, Occupational and Organizational Psychology and Behavior, 26(7), 755-775. doi:10.1002/ job.337

Eng, P. M., Fitzmaurice, G., Kubzansky, L. D., Rimm, E. B., \& Kawachi, I. (2003). Anger expression and risk of stroke and coronary heart disease among male health professionals. Psychosomatic Medicine, 65(1), 100-110. doi:10.1097/01. psy.0000040949.22044.c6

Fernet, C., Lavigne, G. L., Vallerand, R. J., \& Austin, S. (2014). Fired up with passion: Investigating how job autonomy and passion predict burnout at career start in teachers. Work \& Stress, 28(3), 270-288. doi:10.1080/02678373.2014.93 5524

Fisher, C. D. (2000). Mood and emotions while working: missing pieces of job satisfaction?. Journal of Organizational Behavior: The International Journal of Industrial, Occupational and Organizational Psychology and Behavior, 21(2), 185-202. doi:10.1002/(sici)1099-1379(200003)21:2<185::aidjob34>3.0.co;2-m

Fisher, C. D., \& Ashkanasy, N. M. (2000). The emerging role of emotions in work life: An introduction. Journal of Organizational Behavior: The International Journal of Industrial, Occupational and Organizational Psychology and Behavior, 21(2), 123-129. doi:10.1002/(sici)1099-1379(200003)21:2<123::aidjob33>3.3.co;2-\#

Fitzgerald, S. T., Haythornthwaite, J. A., Suchday, S., \& Ewart, C. K. (2003). Anger in Young Black and White Workers: Effects of Job Control, Dissatisfaction, and Support. Journal of Behavioral Medicine, 26(4), 283-296. doi:10.1023/a:1024228026022

Fredrickson, B. L. (1998). Cultivated emotions: Parental socialization of positive emotions and self-conscious emotions. Psychological Inquiry, 9(4), 279-281. doi:10.1207/s15327965pli0904_4

Glasø, L., Vie, T., Holmdal, G., \& Einarsen, S. (2011). An application of affective events theory to workplace bullying: The role of emotions, trait anxiety, and trait anger. European Psychologist, 16(3), 198-208. doi:10.1027/1016-9040/ a000026

Glomb, T. M., Steel, P. D., \& Arvey, R. D. (2002). Office sneers, snipes, and stab wounds: Antecedents, consequences, and implications of workplace violence and aggression. In R. Lord, R. Klimoski, \& R. Kanfer (Eds.), Frontiers of Industrial and Organizational Psychology: Emotions and Work (pp. 227-259). San Francisco: Jossey-Bass.

Gollob, H. \& Reichardt, C. (1991). Interpreting and estimating indirect effects assuming time lags really matter. In L. Collins, \& J. Horn (Eds.), Best Methods for the Analysis of Change: Recent Advances, Unanswered Questions, Future Directions (pp. 243-259). Washington: American Psychological Association. doi:10.1037/10099-015 
Grandey, A. A., Tam, A. P., \& Brauburger, A. L. (2002). Affective States and Traits in the Workplace: Diary and Survey Data from Young Workers. Motivation \& Emotion, 26(1), 31-55. doi:10.1023/A:1015142124306

Gray, J. R. (2001). Emotional modulation of cognitive control: Approach-withdrawal states double-dissociate spatial from verbal two-back task performance. Journal of Experimental Psychology: General, 130(3), 436-452. doi:10 $.1037 / / 0096-3445.130 .3 .436$

Hakanen, J. J., Schaufeli, W. B., \& Ahola, K. (2008). The Job Demands-Resources model: A three-year cross-lagged study of burnout, depression, commitment, and work engagement. Work \& Stress, 22(3), 224-241. doi:10.1080/02678370802379432

Hoyle, R. H. (1995). The structural equation modeling approach: Basic concepts and fundamental issues. In R. H. Hoyle (Ed.), Structural Equation Modeling, Concepts, Issues, and Applications (pp. 1-15). Thousand Oaks, CA: Sage.

$\mathrm{Hu}$, L., \& Bentler, P. M. (1999). Cutoff criteria for fit indexes in covariance structure analysis: Conventional criteria versus new alternatives. Structural Equation Modeling: A Multidisciplinary Journal, 6, 1-55. doi:10.1080/10705519909540118

Hülsheger, U. R., \& Schewe, A. F. (2011). On the costs and benefits of emotional labor: A meta-analysis of three decades of research. Journal Of Occupational Health Psychology, 16(3), 361-389. doi:10.1037/a0022876

Innstrand, S., Langballe, E., \& Falkum, E. (2012). A Longitudinal Study of the Relationship between Work Engagement and Symptoms of Anxiety and Depression. Stress \& Health: Journal of the International Society for the Investigation of Stress, 28(1), 1-10. doi:10.1002/smi.1395

Isen, A. M., (2008). Positive affect and decision processes: some recent theoretical developments with practical implications. In C. F. R. Haugdvedt, P. H. Herr, \& F. R. Kardes (Eds), Handbook of Consumer Psychology (pp. 273-296). New York, NY: Erlbaum. doi:10.1207/153276601750408311

Johnson, P. R., \& Indvik, J. (2000). Rebels, criticizers, backstabbers, and busybodies: Anger and aggression at work. Public Personnel Management, 29(2), 165-174. doi:10.1177/009102600002900201

Katsaros, K. K., \& Nicolaidis, C. S. (2012). Personal traits, emotions, and attitudes in the workplace: Their effect on managers' tolerance of ambiguity. The Psychologist-Manager Journal, 15(1), 37-55. doi:10.1080/10887156.2012.649 991

Kline, R. B. (2010). Principles and practice of structural equation modeling, third edition. New York: The Guilford Press.

Little, L. M., Simmons, B. L., \& Nelson, D. L. (2007). Health among leaders: Positive and negative affect, engagement and burnout, forgiveness and revenge. Journal of Management Studies, 44(2), 243-260. doi:10.1111/j.14676486.2007.00687.x 
Lively, K. J. (2006). Emotions in the Workplace. In: Stets J. E., \& Turner J. H. (Eds.), Handbook of the Sociology of Emotions: Handbooks of Sociology and Social Research (pp. 569-590). Springer, Boston, MA. doi:10.1007/978-0-387-3071 5-2_25

Lively, K. J., \& Powell, B. (2006). Emotional Expression at Work and at Home: Domain, Status, or Individual Characteristics?. Social Psychology Quarterly, 69(1), 17-38. doi:10.1177/019027250606900103

Locke, E. A., \& Latham, G. P. (1990). A theory of goal setting \& task performance. Englewood Cliffs, NJ, US: Prentice-Hall, Inc. doi:10.5860/choice.28-0608

Mäkikangas, A., Bakker, A. B., Aunola, K., \& Demerouti, E. (2010). Job resources and flow at work: Modelling the relationship via latent growth curve and mixture model methodology. Journal of Occupational and Organizational Psychology, 83(3), 795-814. doi:10.1348/096317909x476333

Maslach, C., \& Leiter, M. P. (2008). Early predictors of job burnout and engagement. Journal of Applied Psychology, 93(3), 498-512. doi:10.1037/0021-9010.93.3.498

Mignonac, K., \& Herrbach, O. (2004). Linking work events, affective states, and attitudes: an empirical study of managers' emotions. Journal of Business \& Psychology, 19(2), 221-240. doi:10.1007/s10869-004-0549-3

Milfont, T. L., Denny, S., Ameratunga, S., Robinson, E., \& Merry, S. (2008). Burnout and wellbeing: Testing the Copenhagen burnout inventory in New Zealand teachers. Social Indicators Research, 89(1), 169-177. doi:10.1007/ s11205-007-9229-9

Mogoase, C., \& Stefan, S. (2013). Is there a difference between functional and dysfunctional negative emotions? The preliminary validation of the functional and dysfunctional negative emotions scale (FADNES). Journal of EvidenceBased Psychotherapies, 13(1), 13-32.

Muchinsky, P. M. (2000). Emotions in the workplace: The neglect of organizational behavior. Journal of Organizational Behavior, 21(7), 801-805. doi:10.1002/1099-1379(200011)21:7<801::AID-JOB999>3.0.C0;2-A

Popov, B., Miljanović, M., Stojaković, M., \& Matanović, J. (2013). Work stressors, distress, and burnout: the role of coping strategies. Applied Psychology, 6(4), 355-370. doi:10.19090/pp.2013.4.355-370

Popov, B., Raković, S., \& Jelić, D. (2017). Model organizacijskog zdravlja: predikcija blagostanja zaposlenih i organizacijske uspešnosti [Organizational health framework: Predicting employee well-being and organisational performance]. Primenjena psihologija, 10(1), 81-101. doi:10.19090/ pp.2017.1.81-101

Schaufeli, W. B., \& Greenglass, E. R. (2001). Introduction to special issue on burnout and health. Psychology \& Health, 16(5), 501-510. doi:10.1080/08870440108405523 
Sloan, M. M. (2012). Controlling Anger and Happiness at Work: An Examination of Gender Differences. Gender, Work \& Organization, 19(4), 370-391. doi:10.1111/j.1468-0432.2010.00518.x

Smith, L. A., Roman, A., Dollard, M. F., Winefield, A. H., \& Siegrist, J. (2005). Effortreward imbalance at work: the effects of work stress on anger and cardiovascular disease symptoms in a community sample. Stress and Health: Journal of the International Society for the Investigation of Stress, 21(2), 113-128. doi:10.1002/smi.1045

Spector, P. E., \& Fox, S. (2005). The Stressor-Emotion Model of Counterproductive Work Behavior. In S. Fox, \& P. E. Spector (Eds.), Counterproductive Work Behavior: Investigations of Actors and Targets (pp. 151-174). Washington, DC, US: American Psychological Association. doi:10.1037/10893-007

Stets, J. E., \& Tsushima, T. M. (2001). Negative emotion and coping responses within identity control theory. Social Psychology Quarterly, 64(3), 283-295. doi:10.2307/3090117

Testa, M. R. (2001). Organizational commitment, job satisfaction, and effort in the service environment. The Journal of Psychology: Interdisciplinary and Applied,135(2), 226-236. doi:10.1080/00223980109603693

Tiba, A., \& Szentagotai, A. (2005). Positive emotions and irrational beliefs. Dysfunctional positive emotions in healthy individuals. Journal of Cognitive \& Behavioral Psychotherapies, 5(1), 53-73. doi:10.1037/t41838-000

Tobert, S., \& Moneta, G. B. (2013). Flow as a Function of Affect and Coping in the Workplace. Individual Differences Research, 11(3), 102-113.

Tripp, T.M. \& Bies, R.J. (2010). "Righteous" Anger and Revenge in the Workplace: The Fantasies, the Feuds, the Forgiveness. In M. Potegal, G. Stemmler, \& C. Spielberger (Eds.), International Handbook of Anger (pp. 413-431). New York, NY: Springer. doi:10.1007/978-0-387-89676-2_24

van Vegchel, N., de Jonge, J., Meijer, T., \& Hamers, J. H. (2001). Different effort constructs and effort-reward imbalance: effects on employee well-being in ancillary health care workers. Journal of Advanced Nursing, 34(1), 128-136. doi:10.1046/j.1365-2648.2001.3411726.x

Yang, J., \& Diefendorff, J. M. (2009). The relations of daily counterproductive workplace behavior with emotions, situational antecedents, and personality moderators: A diary study in Hong Kong. Personnel Psychology, 62(2), 259-295. doi:10.1111/j.1744-6570.2009.01138.x

Zellars, K. L., Hochwarter, W. A., Perrewe, P. L., Hoffman, N., \& Ford, E. W. (2004). Experiencing job burnout: The roles of positive and negative traits and states. Journal of Applied Social Psychology, 34(5), 887-911. doi:10.1111/j.1559-1816.2004.tb02576.x 


\section{Boris Popov \\ Dragana Jelić \\ Sara Raković \\ Jelena Matanović}

Odsek za psihologiju, Filozofski fakultet, Univerzitet u Novom Sadu

\section{EMOCIJE I IZGARANJE NA RADU IZ REBT PERSPEKTIVE: KRATKA PROSPEKTIVNA STUDIJA}

Cilj istraživanja bio je da se testira REBT model emocija u predikciji izgaranja na radu. Na osnovu pretpostavki modela, pretpostavljeno je da će disfunkcionalne negativne emocije (DNE) ostvariti pozitivan efekat na izgaranje, da će pozitivne emocije ostvariti (PE) ostvariti negativan efekat na izgaranje, a da će efekat funkcionalnih negativnih emocija (FNE) biti neznačajan. Kako bi se testirale postavljene hipoteze, sprovedena je kratka longitudinalna studija, sa ukupnim trajanjem od 12 nedelja (tri merenja sa po šest nedelja razmaka između svakog merenja). Učešće u prvom merenju uzelo je 197 zaposlenih ispitanika (60.3\% žena). Usled osipanja uzorka, ukupno 113 ispitanika (64.6\% žena) imalo je validne odgovore na sva tri merenja (Little MCAR test neznačajan, sugerišući da su nedostajući podaci slučajno raspoređeni). Ispitanici su popunili Skalu izgaranja iz Kopenhagen inventara izgaranja i listu funckionalnih i disfunkcionalnih emocija, kreiranu za potrebe istraživanja. Na osnovu rezultata može se zaključiti da je obrnuti kauzalni model pokazao bolje indekse podesnosti u poređenju sa kauzalnim, sugerišući da je verovatnije da izgaranje predviđa emocije, nego obrnuto. Što je još interesantnije, izgaranje je ostvarilo veći efekat na FNE, nego na DNE. Ipak, u istoj vremenskoj tačci je slučaj obrnut - izgleda da emocije predviđaju izgaranje, pre nego obrnuto. Štaviše, u vremenu merenja 3, FNE su ostvarile veći (iako veoma sličan) efekat na izgaranje, u poređenju sa DNE. U vremenu 2, jedino DNE su ostvarile značajan efekat na izgaranje. Konačno, PE nisu ostvarile značajan efekat na izgaranje. Rezultati su komentarisani iz ugla REBT teorijskog modela emocija. Na samom kraju rada, prodiskutovana su ograničenja studije, kao i preporuke za buduća istraživanja.

Ključne reči: disfunkcionalne negativne emocije, funkcionalne negativne emocije, izgaranje na radu, pozitivne emocije, REBT model emocija 